\title{
2006-653: DESIGN FOR MANUFACTURE AND ASSEMBLY: A SURVEY OF DESIRED COMPETENCIES
}

\section{Rudolph Eggert, Boise State University}

RUDY J. EGGERT is a Professor in the Department of Mechanical Engineering at Boise State University. His research interests include Engineering Design, Optimization, Design Theory and Methodology, Machine Design, and Probabilistic Analysis. In addition to a number of conference papers and journal articles he recently wrote Engineering Design, published by Prentice Hall in 2004. 


\title{
Design for Manufacture and Assembly: A Survey of Desired Student Competencies
}

\begin{abstract}
Research conducted in 2003 identified major gaps in the supply and demand for engineering design education including design for manufacturing (DFM) and design for assembly (DFA). This paper presents the results of a subsequent research effort conducted during the fall of 2005 to identify specific competencies desired by industry and academia. In addition, a variety of learning experiences desired by industry were compared to those actually provided by academia.

While industry and academia largely agree upon DFM, manufacturing processes and materials competencies, the data suggest that industry would like more emphasis on the following DFA competencies: a) identifying part features or characteristics that affect part insertion and fastening, b) identifying part features or characteristics that affect part handling and c) using solid modeling software to verify that mating parts will assemble.

The data also suggest that industry desires more emphasis on the following "class-room" learning experiences: a) complete a design project using DFMA guidelines/checklists and b) make a part using rapid prototyping; and "non class-room" learning experiences: a) visit local industry, b) do a summer internship in industry, c) complete a term in industry (co-op ed.).

Lastly, the data show that most engineers do not learn their DFMA methods and concepts in their undergraduate program. Rather, they learn them via "on-site" training.
\end{abstract}

\section{Introduction}

Many engineers work in jobs, directly or indirectly, related to manufacturing. The United States Bureau of Labor Statistics reported that 1,449,000 engineers were employed in 2004 [1]. Of those, approximately 38 percent worked directly in manufacturing, 27 percent worked in technical services (including scientific research and development services), 13 percent in government, three percent self-employed and about 19 percent were classified as others.

Manufacturing establishments include: aerospace, apparel and other textile products, chemicals manufacturing (except drugs), drug manufacturing, electronic equipment manufacturing, food processing, motor vehicle and equipment manufacturing, printing and publishing, steel manufacturing, and textile mill products. Technical services which account for approximately one out of four engineering jobs, refer to companies such as Architect and Engineering companies that often design and construct local, state, federal commercial and industrial facilities.

Since engineering design is an essential activity in the product realization process [2], whether one designs products, processes or systems, graduating engineers should be reasonably competent in fundamental design methods and knowledge. A survey of industry was carried out in 2003 to better understand which specific topics and activities that industry desires [3]. In 
addition, colleges were similarly surveyed to better tally what undergraduates were actually being taught.

Industry participants submitted 1006 responses and academia 182, mostly from across the United States and Canada. An analysis of the data indicated that academia appears to be educating undergraduates to meet industry's demand for Engineering Design Specifications, Teamwork and Overall Design Process topics. However, there appears to be a supply gap in academia's current coverage of Design for Manufacture (DFM), Design for Assembly (DFA), Creativity Methods, Project management and Product Testing. In addition Industry has a higher demand for Individual Design Projects and Interdisciplinary Design Project activities, in relation to Academia's current coverage. And lastly, it appears that academia overemphasizes oral and written design report activities.

Design for Manufacture and Design for Assembly competencies were listed as single line items on each questionnaire without any partitioning into sub-topics in the 2003 survey. This permitted a lot self-interpretation with respect to which sub-topics were desirable. Therefore, recognizing industry's strong desire to have graduating engineers competent in DFA and DFM, another research effort was completed in 2005 aimed at identifying specific DFMA competencies. This paper presents that effort in the following section including the survey methodology, respondent characteristics, and competencies in DFA, DFM, manufacturing processes, and materials.

\section{Survey Methodology}

During the fall of 2005, emails were sent to 12,343 members of the American Society of Mechanical Engineers Design Division (ASME) and 732 members of the American Society of Engineering Education Design Division (ASEE). Both ASME and ASEE include engineers that work in industry or academia. Each email invited the recipient to connect to either an industryemployed or academia-employed questionnaire website to answer a number of questions. The answers were automatically appended to a secure spreadsheet for later tabulation and analysis.

Survey respondents were asked to checkmark specific competencies of graduating mechanical engineers using the five-point Likert scale ranging between strongly agree and strongly disagree. An additional checkbox provided for "no opinion." In addition, respondents selected "most-important" competencies. And lastly, demographic information was entered. The original questionnaires are available at: http://coen.boisestate.edu/REGGERT/ .

\section{Respondent Characteristics}

Industry respondents totaled 493, most of these had job titles of Mechanical Engineer $(245,49.7 \%)$ and Engineering Manager $(103,20.9 \%)$, as shown in table 1. Of the total, 451 $(91.5 \%)$ conducted design activities at their worksite. Additional work-site activities included fabricating parts $(318,64.5 \%)$, assembling $(361,73.2 \%)$ and materials processing $(218,44.2 \%)$. A majority of the respondents $(310,61.1 \%)$ conducted three activities (designed, fabricated and assembled). Roughly half $(256,51.9 \%)$ worked at sites employing more than 300 people.

Academic respondents totaled 103, of which full professors represented the majority of respondents $(44,42.7 \%)$ and associate professors represented the next largest group $(25,24.3 \%)$. Although a specific question was not included in the questionnaire, a rough tally of e-mail 
addresses of those respondents wishing to receive a summary report indicated that about $40 \%$ were from Ph.D. granting institutions.

\section{Table 1. Respondent characteristics.}

Industry respondent job/position title

\begin{tabular}{|c|c|c|c|c|c|c|c|}
\cline { 2 - 8 } \multicolumn{1}{c|}{} & $\begin{array}{c}\text { Mechanical } \\
\text { Engineer }\end{array}$ & $\begin{array}{c}\text { Mfg. } \\
\text { Engineer }\end{array}$ & $\begin{array}{c}\text { Project } \\
\text { Engineer }\end{array}$ & $\begin{array}{c}\text { Eng. } \\
\text { Manager }\end{array}$ & $\begin{array}{c}\text { Mfg. } \\
\text { Manager }\end{array}$ & other & total \\
\hline$\#$ & 245 & 19 & 65 & 103 & 9 & 52 & 493 \\
\hline$\%$ & 49.7 & 3.9 & 13.2 & 20.9 & 1.8 & 10.5 & 100 \\
\hline
\end{tabular}

Activities occurring at industry respondent's site

\begin{tabular}{|c|c|c|c|c|c|c|c|}
\cline { 2 - 8 } \multicolumn{1}{c|}{} & design & $\begin{array}{c}\text { fabricate } \\
\text { parts }\end{array}$ & $\begin{array}{c}\text { assemble } \\
\text { parts }\end{array}$ & $\begin{array}{c}\text { process } \\
\text { materials }\end{array}$ & other & $\begin{array}{c}\text { design \& } \\
\text { fabricate }\end{array}$ & $\begin{array}{c}\text { design, fabricate } \\
\text { \& assemble }\end{array}$ \\
\hline$\#$ & 451 & 318 & 361 & 218 & 78 & 312 & 301 \\
\hline$\%$ & 91.5 & 64.5 & 73.2 & 44.2 & 15.8 & 63.3 & 61.1 \\
\hline
\end{tabular}

Number of employees working at industry respondent's jobsite

\begin{tabular}{|c|c|c|c|c|c|c|c|}
\cline { 2 - 8 } \multicolumn{1}{c|}{} & $<10$ & $11-25$ & $26-75$ & $76-150$ & $151-300$ & $>300$ & total \\
\hline$\#$ & 53 & 21 & 40 & 60 & 63 & 256 & 493 \\
\hline$\%$ & 10.8 & 4.3 & 8.1 & 12.2 & 12.8 & 51.9 & 100 \\
\hline
\end{tabular}

Academic respondent job/position title

\begin{tabular}{|c|c|c|c|c|c|c|c|}
\hline $\begin{array}{c}\text { Full } \\
\text { Prof }\end{array}$ & $\begin{array}{c}\text { Associate } \\
\text { Prof }\end{array}$ & $\begin{array}{c}\text { Assistant } \\
\text { Prof }\end{array}$ & $\begin{array}{c}\text { Research } \\
\text { Prof }\end{array}$ & Lecturer & $\begin{array}{c}\text { Graduate } \\
\text { Student }\end{array}$ & other & total \\
\hline 44 & 25 & 14 & 1 & 8 & 2 & 9 & 103 \\
\hline 42.7 & 24.3 & 13.6 & 1.0 & 7.8 & 1.9 & 8.7 & 100 \\
\hline
\end{tabular}

\section{Design for Assembly Competencies}

Design for assembly can be defined as a set of practices that aim to reduce the time and cost required to assemble a product by examining and designing (or re-designing) mating part features to improve part handling, insertion and fastening. For example, we might add a countersink to a hole to facilitate the insertion of a screw. Or we might eliminate the screw altogether by redesigning the mating parts to have snap-fit features.

A variety of sources were used to identify specific DFA competencies including books by the Society of Manufacturing Engineers (SME) [4], Anderson [5], Bralla [6], and Boothroyd, Dewhurst and Knight [7]. A list of competencies followed the proposition "Mechanical engineering graduates should be able to... " Respondents check-marked one of six boxes that ranged between "strongly agree" and "strongly disagree" or "no opinion." Each respondent was then asked to select the most important competency. 
The raw data, giving the total number of responses to all the questions, are available at the following website: http://coen.boisestate.edu/REGGERT/DFMA/DFMASurveyPage.htm . The percentage of industry or academic respondents that offered an opinion was calculated and is presented in Table 2 Design for Assembly Competencies.

Table 2. Design for Assembly Competencies.

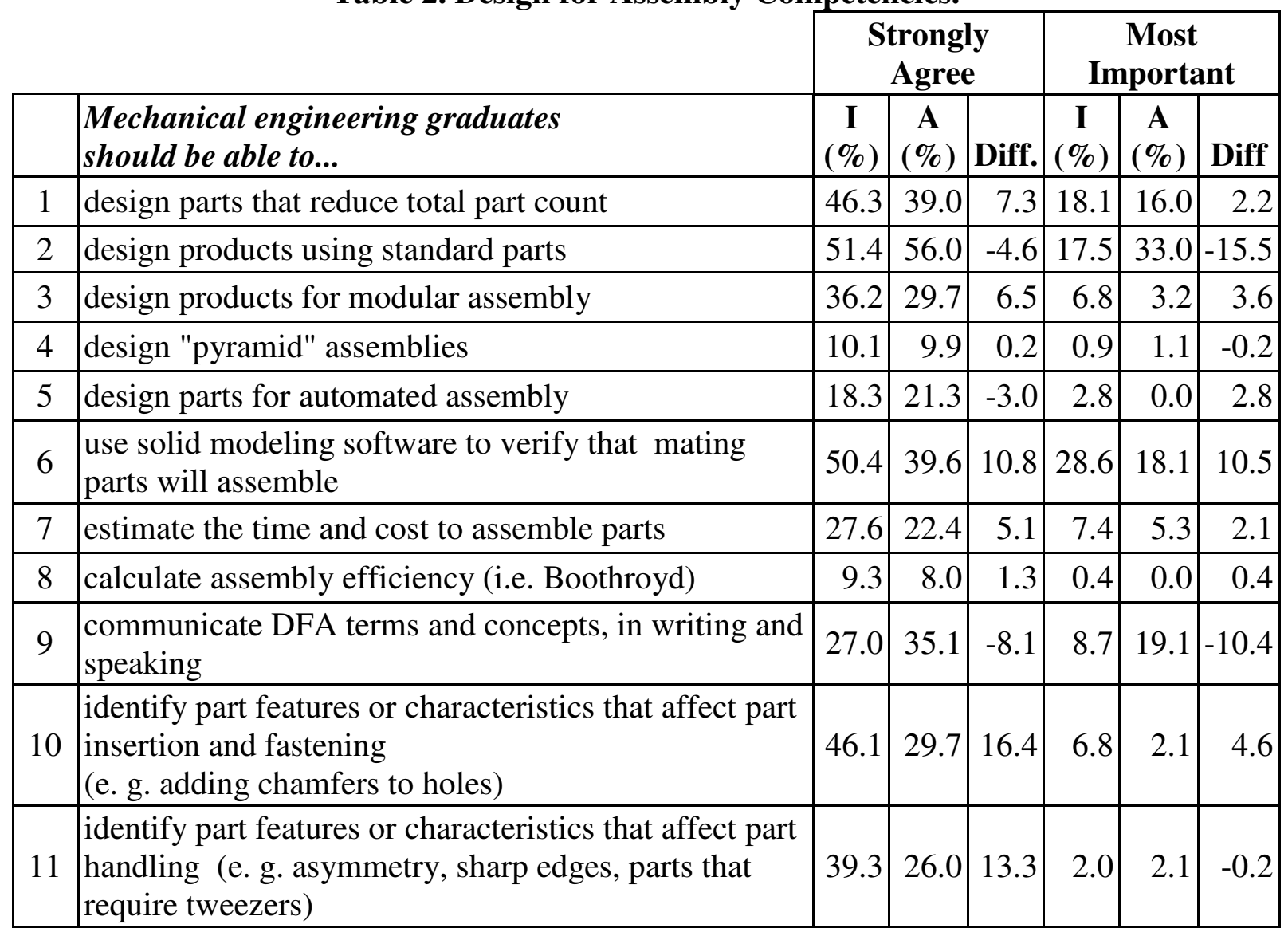

Scanning the "Strongly Agree" industry column (sub-labeled "I") in table 2, we see that industry feels quite strongly that mechanical engineers (MEs) should be able to: a) design products using standard parts $(51.4 \%)$, b) use solid modeling to verify assemblies $(50.4 \%)$, c) design parts that reduce total part count (46.3\%) and d) identify part features or characteristics that affect part insertion and fastening (46.1\%). Scanning down the strongly agree - academia column (labeled "A"), we see that academia values almost the same competencies. We also note that both industry and academia gave low ratings for competencies relating to pyramid assembly and calculating assembly efficiency.

It is interesting to note, however, that when scanning down the difference column (labeled "diff.") we see that more industry respondents strongly agree (than academia respondents) that MEs should be able to: a) identify part features or characteristics that affect part insertion and fastening (16.4\% difference), b) identify part features or characteristics that affect part handling (13.3\%) and c) use solid modeling software to verify that mating parts will assemble (10.8\%). A positive difference indicates that more industry respondents strongly agree 
than academia. A negative difference means that academia feels more strongly. For example, we see that academia feels more strongly about communicating skills than industry $(-8.1 \%)$.

When asked to select the most important DFA competency, industry selected "use solid modeling to verify..." (I-28.6\%, A-18.1\%, Diff. 10.5\%). The positive $+10.5 \%$ difference indicates industry's desire for more emphasis. Academia selected "design products using standard parts" (I -17.5\%, A-33.0\%, Diff. -15.5\%), illustrating academia's desire to emphasize that competency more than industry. Note also that industry feels less inclined to emphasize DFA communication skills (-10.4\%).

The questionnaire permitted industry and academic respondents to list "other" DFA competencies that were not listed in items 1-11 above. They are listed in their entirety on the survey website. A number of items were mentioned once or twice, however industry mentioned a) tolerances (dimensioning and stack-up) 23 times and b) geometric tolerancing and dimensioning 13 times. Academia mentioned tolerances 3 times.

\section{Design for Manufacture Competencies}

Design for Manufacture can be defined as the set of practices that aim to reduce the time and cost to fabricate a part by considering part features, material compatibilities, manufacturing process capabilities and part function. For example, we might avoid specifying thick wall sections for a die cast part to reduce cycle time. In another case, we might specify liberal tolerances for a machined part to reduce process time and cost.

Various DFM competencies were identified from the same sources mentioned for DFA. Industry and academia survey questionnaires were identically formatted and respondents were similarly able to choose boxes ranging between "strongly agree" and "strongly disagree" or "no opinion." Then, each respondent was asked to select the most important competency.

The percentage of industry or academic respondents who offered an opinion was calculated and is presented in Table 3 Design for Manufacture Competencies.

Table 3. Design for Manufacture Competencies.

\begin{tabular}{|l|l|c|c|c|c|c|c|}
\multicolumn{2}{l}{} & \multicolumn{3}{l|}{ Strongly Agree } & \multicolumn{3}{l|}{ Most Important } \\
\hline \multicolumn{2}{l}{$\begin{array}{l}\text { When designing a part for fabrication, mechanical } \\
\text { engineering graduates should be able to... }\end{array}$} & $\begin{array}{c}\text { I } \\
(\%)\end{array}$ & $\begin{array}{c}\mathbf{A} \\
(\%)\end{array}$ & Diff. & $\begin{array}{c}\text { I } \\
(\%)\end{array}$ & $\begin{array}{c}\text { A } \\
(\%)\end{array}$ & Diff. \\
\hline 12 & $\begin{array}{l}\text { identify part features or characteristics that influence } \\
\text { tooling costs }\end{array}$ & 42.5 & 37.6 & 4.8 & 21.0 & 18.9 & 2.1 \\
\hline 13 & $\begin{array}{l}\text { identify part features or characteristics that influence } \\
\text { processing time }\end{array}$ & 40.6 & 34.0 & 6.6 & 20.3 & 13.3 & 7.0 \\
\hline 14 & design a part using solid modeling software & 43.1 & 48.0 & -5.0 & 26.9 & 32.2 & -5.4 \\
\hline 15 & estimate material, tooling and processing costs & 17.9 & 17.0 & 0.9 & 13.8 & 8.9 & 4.9 \\
\hline 16 & $\begin{array}{l}\text { communicate DFM terms and concepts, in writing and } \\
\text { speaking }\end{array}$ & 26.1 & 31.7 & -5.6 & 12.2 & 16.7 & -4.5 \\
\hline 17 & $\begin{array}{l}\text { determine material compatibilities of alternative } \\
\text { manufacturing processes }\end{array}$ & 23.2 & 25.5 & -2.3 & 5.9 & 10.0 & -4.1 \\
\hline
\end{tabular}


Scanning the strongly agree column we see that industry strongly desires competencies such as: a) design a part using solid modeling software $43.1 \%$ ), b) identify part features or characteristics that influence tooling costs $(42.5 \%)$ and c) identify part features or characteristics that influence processing time $(40.6 \%)$. Academia similarly values the same competencies, with some differences in emphasis $(48.0 \%, 37.6$, and $34.0 \%$ respectively).

Industry's first, second and third most important DFM competencies were: a) design a part using solid modeling software $(26.9 \%)$, b) identify part features or characteristics that influence tooling costs $(21.0 \%)$ and c) identify part features or characteristics that influence processing costs $(20.3 \%)$. Academia agreed with industry's first and second choice, but placed communication third. Scanning the difference columns we see that industry would like a little more emphasis in identifying part features and characteristics that influence processing costs $(+7 \%)$.

Various "Other DFM competencies" were suggested by industry and academia. However, academia most frequently mentioned cost/economical production 3 times while industry most frequently mentioned tolerances 8 times and geometric dimensioning and tolerancing 3 times.

\section{Manufacturing Processes Competencies}

Manufacturing processes were categorized into seven selections: machining, casting, polymer, sheet metal, bulk deformation, consolidating, and finishing. These are shown in Table 4. Manufacturing Process Competencies.

Under the strongly agree columns we see that industry and academia overwhelmingly chose machining as the most desirable competency. Industry's second and third choices were sheet metal $(35.9 \%)$ and polymer (31.5\%). Academia's second and third choices were casting (40\%) and polymer (39\%).

Table 4. Manufacturing Process Competencies.

\begin{tabular}{|c|c|c|c|c|c|c|c|}
\hline \multirow{2}{*}{\multicolumn{2}{|c|}{$\begin{array}{l}\text { Mechanical engineering graduates should be able to } \\
\text { design parts that make use of the following processes: }\end{array}$}} & \multicolumn{3}{|c|}{ Strongly Agree } & \multicolumn{3}{|c|}{ Most Important } \\
\hline & & $\begin{array}{c}\text { I } \\
(\%)\end{array}$ & $\begin{array}{c}\mathrm{A} \\
(\%)\end{array}$ & Diff & \begin{tabular}{|c|} 
I \\
$(\%)$
\end{tabular} & $\begin{array}{c}\mathrm{A} \\
(\%)\end{array}$ & Diff \\
\hline 1 & $\begin{array}{l}\text { Machining } \\
\text { e.g. drill, bore, turn, grind, saw }\end{array}$ & 53.8 & 61.0 & -7.2 & 70.1 & 76.2 & -6.1 \\
\hline 2 & $\begin{array}{l}\text { Casting } \\
\text { e.g. die, sand, investment }\end{array}$ & 29.5 & 40.0 & -10.5 & 2.4 & 4.8 & -2.4 \\
\hline 3 & $\begin{array}{l}\text { Polymer } \\
\text { e.g. injection mold, cast, blow mold }\end{array}$ & 31.6 & 39.0 & -7.4 & 15.6 & 14.3 & 1.3 \\
\hline 4 & $\begin{array}{l}\text { sheet metal } \\
\text { e.g. shear, blank, punch, bend }\end{array}$ & 35.9 & 37.0 & -1.1 & 5.1 & 3.2 & 1.9 \\
\hline 5 & $\begin{array}{l}\text { bulk deformation } \\
\text { e.g. roll, draw, extrude }\end{array}$ & 17.7 & 23.0 & -5.3 & 0.0 & 0.0 & 0.0 \\
\hline 6 & $\begin{array}{l}\text { consolidating } \\
\text { e.g. weld, braze, solder, adhesive bond }\end{array}$ & 31.0 & 38.0 & -7.0 & 4.5 & 1.6 & 2.9 \\
\hline 7 & $\begin{array}{l}\text { finishing } \\
\text { e.g. polish, paint, plat, anodize }\end{array}$ & 26.8 & 21.0 & 5.8 & 2.4 & 0.0 & 2.4 \\
\hline
\end{tabular}


When asked to select the most important process, both industry and academia selected as their first and second choices: machining (I-70.1\%, A-76.2\%) and polymer (I-15.6\%, A-14.3\%). Various "other processes" were suggested to a lesser extent, including powder metals, welding, forging, and electro discharge machining.

\section{Material Competencies}

As shown in Table 5. Material Competencies, industry and academia both selected metals and polymers as their first and second choice. When asked about "other" materials industry had repeated entries for wood (6) and elastomers (9).

Table 5. Material Competencies

\begin{tabular}{|l|l|r|r|r|r|r|r|}
\cline { 3 - 8 } \multicolumn{2}{c|}{} & \multicolumn{3}{|c|}{ Strongly Agree } & \multicolumn{3}{|c|}{ Most Important } \\
\hline & $\begin{array}{l}\text { Mechanical engineering graduates should be } \\
\text { able to design parts that use the } \\
\text { following materials... }\end{array}$ & $\begin{array}{c}\text { I } \\
(\%)\end{array}$ & $\begin{array}{c}\text { A } \\
(\%)\end{array}$ & $\mathbf{D i f f}$ & $\begin{array}{c}\text { I } \\
(\%)\end{array}$ & $\begin{array}{c}\text { A } \\
(\%)\end{array}$ & Diff \\
\hline 1 & Metals & 69.8 & 71.6 & -1.8 & 74.8 & 80.5 & -5.7 \\
\hline 2 & Polymers & 44.1 & 51.0 & -6.9 & 18.2 & 11.7 & 6.5 \\
\hline 3 & Ceramics & 14.3 & 12.7 & 1.5 & 0.5 & 0.0 & 0.5 \\
\hline 4 & composites & 23.6 & 30.4 & -6.8 & 6.4 & 7.8 & -1.4 \\
\hline
\end{tabular}

\section{Learning Experiences Desired}

Learning experiences are the educational means by which DFMA knowledge is introduced and individual competencies are developed. Nine learning experiences, as shown in Table 6, were listed as a "should" have proposition, stated as "As part of their undergraduate education, mechanical engineering students should..." In other words, respondents were rating their agreement as to the desirability of each of the learning experiences.

Examining the strongly agree column, we see that "designing a part using CAD/Solid Modeling" is the most favored learning experience chosen by both industry and academia (I-64.0\%, A-64.7\%). Industry's second most desirable learning experience is "completing an assembly using CAD/Solid Modeling" (57.5\%). If we limit our discussion to items 1 thru 6, to exclude non-classroom experiences, then industry's third choice is "fabricate a part using machine tools" (49.9\%). Academia's second choice is "fabricate a part using machine tools" (56.9\%), with "completing an assembly using CAD/Solid Modeling" a close third (50.0\%).

Examining the strongly agree-difference column we see that industry would like somewhat more emphasis on a) visit local industry $(12.8 \%)$, b) do a summer internship in industry (13.3\%) and c) complete a term in industry (co-op ed.) (20.1\%).If we examine "classroom" experiences (items 1-6), under the most important columns, we see desires for a) fabricate a part using machine tools (I-21.8\%, , A-20.9\%), b) design a part using CAD/Solid Modeling (I-10.1, A-18.7\%), and c) complete a design and build project using various manufacturing processes (I-14.4\%, A-24.2\%). Note that academia appears to emphasize items 3 
and 6 more than industry does. Also, note that for non-classroom experiences (items 7, 8 and 9), industry likes more emphasis on "complete a term in industry (co-op ed.)."

Table 6. Learning Experiences Desired

\begin{tabular}{|l|l|r|r|r|r|r|r|}
\cline { 2 - 8 } \multicolumn{2}{c|}{} & \multicolumn{3}{c|}{$\begin{array}{c}\text { Strongly } \\
\text { Agree }\end{array}$} & \multicolumn{3}{c|}{$\begin{array}{c}\text { Most } \\
\text { Important }\end{array}$} \\
\hline 1 & $\begin{array}{c}\text { I } \\
(\%)\end{array}$ & $\begin{array}{c}\text { A } \\
(\%)\end{array}$ & Diff & $\begin{array}{c}\text { I } \\
(\%)\end{array}$ & $\begin{array}{c}\text { A } \\
(\%)\end{array}$ & Diff \\
\hline 1 & $\begin{array}{l}\text { fabricate a part using machine tools } \\
\text { e.g. lathe, welder, mill, grinder }\end{array}$ & 49.9 & 56.9 & -7.0 & 21.8 & 20.9 & 1.0 \\
\hline 2 & Make a part using rapid prototyping & 21.9 & 19.6 & 2.3 & 0.5 & 1.1 & -0.6 \\
\hline 3 & design a part using CAD/Solid Modeling & 64.0 & 64.7 & -0.7 & 10.1 & 18.7 & -8.5 \\
\hline 4 & $\begin{array}{l}\text { complete an assembly using CAD/Solid } \\
\text { Modeling }\end{array}$ & 57.5 & 50.0 & 7.5 & 7.9 & 4.4 & 3.5 \\
\hline 5 & $\begin{array}{l}\text { complete a design project using DFMA } \\
\text { guidelines/checklists }\end{array}$ & 32.4 & 24.5 & 7.9 & 7.9 & 5.5 & 2.4 \\
\hline 6 & $\begin{array}{l}\text { complete a design and build project using } \\
\text { various manufacturing processes }\end{array}$ & 38.7 & 47.1 & -8.3 & 14.4 & 24.2 & -9.8 \\
\hline 7 & visit local industry & 54.9 & 42.2 & 12.8 & 3.6 & 2.2 & 1.4 \\
\hline 8 & do a summer internship in industry & 53.5 & 40.2 & 13.3 & 12.2 & 14.3 & -2.1 \\
\hline 9 & complete a term in industry (co-op ed.) & 41.7 & 21.6 & 20.1 & 21.6 & 8.8 & 12.8 \\
\hline
\end{tabular}

\section{Learning Experiences Provided}

A separate survey question asked academia to identify which learning experiences, if any, students actually participated. Written as a mutually exclusive question, they could select either: a) in one or more required courses, b) in elective course(s), c) both or d) neither. The results are shown as percentages in Table 7. Learning Experiences Provided.

Perhaps the most significant column is the "Neither." This column shows the percentage of respondents whose schools do not require the learning experience or offer it as an elective. The largest percentages occur for non-classroom experiences, items 7,8 and 9 (visits, summer internships and Co-op's). While non-classroom experiences are meaningful and desirable, these numbers are understandable considering the resources required and the national trend to reduce total curriculum credit hours.

To determine the total "supply" of DFMA learning experiences the "required" and "both" columns were added. The percentage of industry respondents who marked either strongly agree or agree was added together to produce a total "demand." The "diff." column represents the excess demand for each learning experience.

Analyzing the difference column, we see that non-classroom experiences are very important to industry. Also, we see the largest excess classroom demands for: a) complete a design project using DFMA guidelines/checklists (67.9\%) and b) make a part using rapid prototyping $(44.4 \%)$. 
Table 7. Learning Experiences Provided

\begin{tabular}{|l|l|c|c|c|c|c|c|c|}
\hline $\begin{array}{l}\text { As part of their } \text { undergraduate } \\
\text { education, mechanical engineering } \\
\text { students should... }\end{array}$ & Req'd & Elect. & Both & Neither & Supply & Demand & Diff. \\
\hline 1 & $\begin{array}{l}\text { fabricate a part using machine tools } \\
\text { e.g. lathe, welder, mill, grinder }\end{array}$ & 46.6 & 17.5 & 11.7 & 24.3 & 58.3 & 88.8 & 30.6 \\
\hline 2 & Make a part using rapid prototyping & 22.3 & 33.0 & 2.9 & 41.7 & 25.2 & 69.7 & 44.4 \\
\hline 3 & design a part using CAD/Solid Modeling & 50.5 & 13.6 & 21.4 & 14.6 & 71.8 & 96.8 & 25.0 \\
\hline 4 & $\begin{array}{l}\text { complete an assembly using CAD/Solid } \\
\text { Modeling }\end{array}$ & 41.7 & 20.4 & 16.5 & 21.4 & 58.3 & 91.8 & 33.5 \\
\hline 5 & $\begin{array}{l}\text { complete a design project using DFMA } \\
\text { guidelines/checklists }\end{array}$ & 12.6 & 28.2 & 3.9 & 55.3 & 16.5 & 84.4 & 67.9 \\
\hline 6 & $\begin{array}{l}\text { complete a design and build project using } \\
\text { various manufacturing processes }\end{array}$ & 44.7 & 15.5 & 10.7 & 29.1 & 55.3 & 89.1 & 33.7 \\
\hline 7 & visit local industry & 24.3 & 24.3 & 9.7 & 41.7 & 34.0 & 93.5 & 59.5 \\
\hline 8 & do a summer internship in industry & 6.8 & 29.1 & 1.0 & 63.1 & 7.8 & 89.7 & 81.9 \\
\hline 9 & complete a term in industry (co-op ed.) & 5.8 & 26.2 & 2.9 & 65.0 & 8.7 & 75.8 & 67.1 \\
\hline
\end{tabular}

\section{Where Industry Learns DFMA}

Industry participants check marked boxes where they learned DFMA methods or concepts. The results are presented in table 8. Note that only a small fraction $(22.3 \%)$ of the industry respondents learned DFA and or DFM methods and concepts in their undergraduate program. A majority, however, had on-site training (62.9\%), presumably after graduation.

Table 8. Where industry respondents learned DFMA methods or concepts.

\begin{tabular}{|c|c|c|c|c|c|c|}
\cline { 2 - 7 } \multicolumn{1}{c|}{} & $\begin{array}{c}\text { Undergrad. } \\
\text { college }\end{array}$ & $\begin{array}{c}\text { on-site } \\
\text { training }\end{array}$ & $\begin{array}{c}\text { off-site } \\
\text { workshop }\end{array}$ & $\begin{array}{c}\text { Over } \\
\text { internet }\end{array}$ & other & never \\
\hline$\#$ & 110 & 310 & 67 & 16 & 115 & 49 \\
\hline$\%$ & 22.3 & 62.9 & 13.6 & 3.2 & 23.3 & 9.9 \\
\hline
\end{tabular}

\section{Understanding Our Constituencies}

In product design we attempt to determine our customers' requirements and often summarize them in a detailed engineering design specification. Similarly, under ABET 2000 accreditation guidelines, most if not all U. S. engineering programs have put in place feedback mechanisms to better understand their constituent's needs, including industry's needs, with respect to engineering education. 
The recent survey had 103 academic respondents out of about 350 engineering programs in the United States. Was that because we, in general, are weary of questionnaires and therefore few participated? Or, more hauntingly, is it because there were no "design" faculty on board or DFMA topics taught at those non-responding schools? Did you respond to the questionnaire? How do your numbers compare to the summary statistics?

While this survey and its 2003 predecessor had national participation, they may not have the same types of industry representation as your institution. Therefore, the data and conclusions should be used with caution. However, the survey results and questionnaires might serve as talking points at your next industry advisory panel meeting.

You may wish to do your own local surveys to increase understanding of your constituent's needs. Both the 2003 and 2005 questionnaires were prepared using MS FrontPage software which automatically posts responses to an Excel spreadsheet. Once the questionnaires are created, and invitation emails are sent, the effort reduces to summarizing the data produced in the Excel file. You are encouraged to examine the website, read the "Design Across the Curriculum" summary paper, and examine the questionnaires. Free, electronic copies of each questionnaire will be made available to academic institutions upon request.

\section{Summary}

- Industry desires more emphasis on the following DFA competencies:

a) identify part features or characteristics that affect part insertion and fastening $(16.4 \%$ difference),

b) identify part features or characteristics that affect part handling (13.3\% difference) and

c) use solid modeling software to verify that mating parts will assemble (10.8\%difference).

- Industry and academia generally agree on DFM competencies.

- Industry and academia rank machining as the most important manufacturing process competency. However, industry and academia express different desires for the remaining processes.

- Industry and academia agree that metals and polymer materials are most important.

- Industry desires more emphasis on the following "class-room" learning experiences:

a) complete a design project using DFMA guidelines/checklists and

b) make a part using rapid prototyping.

- Industry desires more emphasis on the following "non class-room" learning experiences:

a) visit local industry

b) do a summer internship in industry

c) complete a term in industry (co-op ed.)

- Most engineers do not learn their DFMA methods and concepts in their undergraduate program. Rather, they learn them via "on-site" training.

\section{Design Website}

Survey questionnaires, raw data, comments and other engineering design information is available at: http://coen.boisestate.edu/REGGERT/ . 


\section{Acknowledgement}

In addition to those academic and industrial participants that volunteered to complete the survey questionnaires, the following organizations were instrumental in making this study possible: ASME Design Engineering Division, ASEE Design Education Division, and Boise State University.

\section{References}

[1] http://stats.bls.gov/oco/ocos027.htm

[2] Engineering Design, Eggert, R. J., Prentice Hall, Inc., 2004, Englewood Cliffs, New Jersey.

[3] Eggert, R. J.; "Engineering Design Education: Surveys of Demand and Supply," Proceedings of the 2003 ASEE Annual Conference \& Exposition, June 2003, Nashville, TN.

[4] Design for Manufacturability, Tool and Manufacturing Engineers Handbook; vol. 6, Society of Manufacturing Engineers, Dearborn, MI, 1992

[5] Anderson, David M., Design for Manufacturability; Optimizing Cost, Quality, and Time-to-Market, 2nd edition, 1990, 2001, CIM Press.

[6] Boothroyd, G., P. Dewhurst, and W. Knight, Product Design for Manufacture and Assembly, Marcel Dekker, New York, 1994.

[7] Bralla, J. G. (ed.), Design for Manufacturability Handbook, McGraw-Hill, New York, N.Y., 1998. 